\title{
A NOTE ON THOMAS LODGE'S A TREATISE OF THE PLAGUE (1603)
}

\author{
by
}

\section{R. S. ROBERTS*}

IN 1968, ${ }^{1}$ in discussing Creighton's History of epidemics ${ }^{2}$ I warned against his acceptance of descriptions of plague by writers such as Gilbert Skeyne and Thomas Lodge $^{3}$ as trustworthy evidence based on real observation of contemporary epidemics; they were, I said, in this respect basically repetitions of what Avicenna ${ }^{4}$ had written over five hundred years earlier. Had I known it at the time, I could have made the point even more strongly in the case of Lodge, for, at the same time that my essay was being published, an article by Elliane Cuvelier proved conclusively that Lodge's $A$ treatise of the plague is essentially a translation of Francois Vallériole's rare Traicté de la peste published in 1566 by Antoine Gryphe of Lyons, which in turn is repetitious of Vallériole's earlier book Loci medicinae communes (also published by the house of Gryphe, in 1562). ${ }^{5}$ What Cuvelier does not note is the debt, in turn, to Avicenna.

*R. S. Roberts, Ph.D., Department of History, University College of Rhodesia, Private Bag 167H, Salisbury. Rhodesia.

1 R. S. Roberts, 'Epidemics and social history', Med. Hist., 1968, 12: 305-316, see p. 311.

2 C. Creighton, A history of epidemics in Britain, 2 vols., Cambridge University Press, 1891-94, (reprint, London, F. Cass, 1965).

: G. Skeyne, Ane breve descriptioun of the pest . . ., Edinburgh, R. Lekprevik, 1568; T. Lodge, $A$ treatise of the plague .... London, for E. White, 1603.

- Canon medicinae .... Venice, Juntae, 1608, 2 vols., II (Lib. Quart., Fen. I., Tract. 4, cap. 3), p. 69.

B E. Cuvelier, 'A treatise of the plague de Thomas Lodge (1603): traduction d'un ouvrage médical français', Etudes Anglaises, 1968, 21 : 395-403. 